\title{
Corporate Social Responsibility and Reciprocity Relations during Covid-19*
}

\author{
Christian Rainero**, Giuseppe Modarelli ${ }^{* * *}$
}

\begin{abstract}
This research work opens an interpretative view on corporate social responsibility $(C S R)$ during an unexpected emergency reality and latent environmental collapse as a strategy to survive. The investigation approach follows the lines of a field analysis survey based on 288 consumers before $(n=80)$ and during the spread of Covid-19 ( $n=208)$. The study aims to provide paradigms and interpretations of evidence-based CSR as a balanced reciprocity relationship in coping emergencies; this necessarily moved the authors to investigate the relationship transversally, examining the role of budgeting and its repercussions on well-being by hierarchical leadership. Specifically, the authors investigate the existence of possible niches of actions based on cooperative and responsible operations during emergencies.
\end{abstract}

Keywords: Covid-19; Leadership; Environmental Collapse; Reciprocity; Corporate Social Responsibility; Global Markets

\section{Introductory Remarks: Paradoxes and Criticism}

The beginning of the year 2020 was marked by the global Covid-19 pandemic. While the scope of the pandemic was initially limited to the territories of China, it has since expanded to affect the entire world population.

Globalization facilitates the rapid spread of epidemics; these follow humans' movements and therefore, unlike in the past, they develop and spread very quickly (Kevany, 2014). In this way, a generalized sanitary urgency condition, in addition to the already dramatic environmental situation, led past governments, and even modern governments today, to vigorously adopt drastic measures. These choices are not free from immanent criticisms and demonstrate many paradoxes. Among these, are the renewed role of power inherent in the budget and the speed or availability of spending as a bargaining strategy, socially and institutionally defining hierarchical leadership perspectives?

In economies and civilizations founded on democracy, governmental processes, although urgent, remain always relatively delayed, demonstrating the inadequacy of

\footnotetext{
* The Authors: Rainero, C. $\S \S 3,4,7$, Modarelli, G. $\S \S 1,2,5,6$

** Associate Professor of Business Administration, University of Turin (christian.rainero@unito.it)

*** Lecturer on Business Administration, University of Turin (giuseppe.modarelli@ unito.it)
}

Edited by: Niccolò Cusano University

ISSN: $1593-0319$

Rainero, C., \& Modarelli, G. (2021). Corporate Social Responsibility and Reciprocity Relations during Covid-19. Symphonya. Emerging Issues in Management (symphonya.unicusano.it), (2), 118-141.

https://dx.doi.org/10.4468/2021.2.10rainero.modarelli 
the institution (Bisio, 2003). Therefore, parallel paths promoted by economic agents on the market is able to react in a timely manner and reach objectives promptly even as the states struggle.

Under the lens of the pandemic situation, new dichotomies are exacerbated between charity and selfishness in a Hobbesian fight for survival. New exclusions, marginalization, and rivalries, however, in parallel would reflect renewed interest in cooperation from the bottom to face upcoming challenges quickly while stable geopolitical unions begin to waver between consensus, prudent behaviours, and mistrust.

The pandemic seems to have highlighted the intrinsic characteristics of human beings at every level, and Covid-19 has shown how populations remain vulnerable (Walsh, 2020) against scarcely controllable external environmental forces.

For the present socio-economic system, in light of the pandemic and in the natural sphere of the survival instincts, the Hobbesian "law of the fittest" seems to prevail over altruistic sentiment precisely in moments of imbalance, which on the contrary would emerge niches of reciprocity.

According to the aforementioned, social antinomies can only find social solutions, and socio-economic imbalances would activate the triggering mechanism of cooperative and reciprocal behaviours, enhancing leadership networks that are no longer strictly hierarchical based on financial availability.

In this direction, the authors attempt to investigate possible strategies based on cooperative and responsible actions during emergencies. While these strategies already existed prior to the pandemic, they have recently been enhanced. They are closely related to coping with the crisis communally through multiplied minimal efforts that provide benefits for the whole society.

On these introductory assumptions, which are characterized by hermeneutic traits, through the observation of recent realities made evident by the Covid-19 emergency, the authors produce insights on corporate social responsibility as an anti-crisis solution. Additionally, the authors explore the following questions: "What lessons can be learned about CSR from the current crisis?" and "How can economic actors face the emergency from the bottom?" The study especially focuses on a caused rethinking of social inequity exacerbated by budgetary leadership power.

The article aims to provide an overview of the situation, concentrating on the hermeneutical efforts on the predominant aspects of emergencies of the Covid-19 pandemic from the perspective of budgetary roles in the socio-economic global context. In addition, through a specific interpretative view, the authors invite the rethinking of inequalities and societal and environmental challenges, suggesting a third way based on humans' natural reciprocity sentiments, including horizontal implications and timely responses to exit the emergency condition and restructuring well-being, which is achievable from a "gift" perspective (Mauss, 1966) as a cooperative direction of leadership (Torfing, Sørensen \& Bentzen, 2019). The economic agents on the market make a strong response observable. In fact, these ones could be able to achieve goals when states seem to delay.

With this framing, the authors propose a field analysis survey based on 288 respondents in Italy. 80 were sampled prior to the outbreak of the pandemic, and 208 were sampled during the first epidemic wave. The survey aimed to verify the existence of horizontal behavioural propensity to reciprocity to cope with the crisis. These approaches shift individual and uneven interests, often dangerous for the community and their achievements, into organic and homogeneous objectives. 


\section{Background}

\subsection{A Cooperative Leadership for CSR and a Timely Crisis Response}

Sustainability is a crucial strategy for the future. The term comes from the 1987 Report provided by the World Commission on Environment and Development (WCED, 1987). In this report, the concept and meaning of the term is summarized as the human responsibility to their needs and satisfaction without affecting possibilities to satisfy future generations' ones.

Nowadays, Covid-19 and the environmental collapse heighten the danger level for human existence; therefore, each economic actor should act responsibly. The emergency conditions is, in a certain sense, a great and unreproducible opportunity to observe the contrasts between cooperation and individualism as shaping paradoxes. Fortunately, the period characterized by non-linearity due to Covid-19, despite its difficulties, seems to have moved the consciousness of several economic agents to act in favour of disadvantaged and imbalanced situations, horizontally activating different strategical channels such as social advertising campaigns, donations, fundraising for charity, production lines re-engineering to meet healthcare needs, and voluntary charitable actions.

The observable increase of CSR interventions have motivated the authors' interest in investigating the connections among public needs, sustainability challenges, and human rights during non-linear emergency periods that are strictly related to private actors' socially responsible interventions as timely anti-crisis cooperative solutions.

Several ambits in CSR studies have been investigated, concerning: reporting (De Villiers, Rinaldi \& Unerman, 2014; Cardamone, Carnevale, Giunta, 2012; Brown \& Dillard, 2014; De Klerk \& De Villiers, 2012; Dumay et al., 2017; Warwick \& Dowler, 2015; Atkins et al., 2015; Simnett \& Huggins, 2015); marketing (Sanclemente-Téllez, 2017) and advertising (Kerr et al., 2008); positive repercussions on products sales (Bhattacharya \& Sen, 2004); loyalty (Iglesias et al., 2020; Sharma, 2019), banking system disclosure (Uddin et al., 2018); religiosity (Mazereeuw et al., 2014); abandonment and data communication of CSR during financial crises (Ken, 2016; Ham \& Kim, 2019); image building (McLennan \& Banks, 2018); network culture and performance (Brondoni, 2003); ethics in international relations (Caselli, 2003); global retailers (Pepe, 2003); supply chain (Tassinari, 2003); corporate governance (Bisio, 2003; Salvioni \& Gennari, 2019); scarcity economy and direct growth of the company and relations (Arrigo, 2003); stakeholder theory (Freeman \& Dmytriyev, 2017) and its evolution (Mosca \& Civera, 2017), etc. In this sense, CSR is considered a multifaceted dimension that is underdeveloped when under the influence of crisis, probably due to the absence of observation points on its role during emergencies, such as the recent pandemic.

For decades, scholars have discussed the connection between business and society, studying interdependencies between CSR and stakeholder theory (Brown \& Forster, 2013; Carroll, 1979; Freeman, 1984). In this sense, the lens of emergency is a privileged point of view for companies to activate CSR as an anti-crisis solution in a facing emerging complexity (OECD, 2001; Zimmerman, Lindberg \& Plsek, 1998). According to the aforementioned, CSR shapes the lines of a trend inversion in 
businesses through influencing their social traits and inherent economic activities and contributing in this way to societal and environmental well-being (Ganti, 2019).

CSR has been demonstrated as a positive influencing factor on companies' financial performance (Handelman \& Stephen, 1999) and the industrial societies in Western modernity have been oriented to performance dominant paradigms (Korhonen, 2002). During emergencies, the reciprocity principles, inherent social and by transition economic agents are renewed.

This view permits going beyond the boundaries of mere shareholders' redistribution (Friedman, 2007), combining timely orientation, cooperativeness, leadership, and reciprocity to overcome the individual barrier of profit. Reciprocity has been considered under several perspectives in the CSR ambit by Luo \& Zheng (2013), Sacconi (2007), Francés-Gómez \& del Rio (2008), Tatli et al. (2014); however, these were not strictly explored during emergency periods.

The frame in which the neoclassical view is forced presumes specific roles for companies in making profits, leaving the stakeholders (Evan \& Freeman, 1988; Freeman, 1984) to serve only as instrumental extensions to their wealth (Friedman, 2007). The direct observation and the literary hermeneutical dimension provided by the authors is consistent with the fact that during non-linear periods. The ontological view on the companies' activities is more prone to the ethical and moral approaches and strategies and not merely for profit (Frey, 2005), equating the survival goal in a more expanded redistribution and cooperatively pursuing, in a certain sense, the common good (Bruni \& Zamagni, 2011; Ostrom, 1990; Rivoli, 1995).

\subsection{Budget Role, Well-Being, CSR, and Emergencies: Paradoxes and Lessons}

Humanity has always faced natural and man-made disasters (Cooper \& Kirton, 2009) with necessary exceptional urgency and through measures taken by governments during these unfavourable events (Sargiacomo, 2015). The recent human crisis arising from the spread of the Covid-19 virus has placed the global community, already affected by socio-economic and environmental imbalances, and humanity in a precarious position that must managed necessarily by new social solutions.

The extent of the catastrophic event has revealed significant system flaws. To the eyes of a management scholar, the flaws are attributable to the reduced consideration over public health as a main objective of state protection. Often, as in Italy, public health has been relegated in favours of performance management. Localisms of a subsidiarity that has favoured quicker responses in different areas, (Lovering, 1999) and has resulted in the pursuit of a self-fulfilling prophecy.

Gurrìa, OECD General Secretary, affirmed that the economic shock due to the recent pandemic is of a greater magnitude than the 2008 financial crisis. Additionally, the uncertainty around the sanitary conditions created by the spread of the virus meant that economies suffered to a more dramatic extent than in the aftermath of the terrorist attacks on September 11, 2001 or the 2008 financial crisis.

On the one hand, the global economic and financial crisis demonstrated a significant impact on all countries already affected by growing societal and environmental imbalances, posing significant challenges to budget policies worldwide (Darvas, 2010). On the other hand, emergency management is once again 
necessary, as it constitutes a complex policy mechanism able to incorporate intergovernmental and multifaceted efforts in mitigating, preparing for, responding to, and exiting the critical moment (Donahue \& Joyce, 2001). Unfortunately, not all states or supra-state entities, (i.e., those intended as intangible institutional social structures devoted to guaranteeing rights and duties) are able to promptly address its needs and requirements, especially in the face of unexpected crises such as the current pandemic, which adds to a countless list of unresolved critical issues.

In fact, many sacrifices have been made over the years to sectors such as education, health, and infrastructure at the national level, while supranational bodies were set up to balance decision-making power. Today, the world community is again witnessing continuous renegotiations, intrinsically incorporating logics of power based on budgets. The common sentiment seems to be the stoppage of funding. While these reforms may offer the best performance, it often disincentives quality, repeating the aforementioned prophecy.

Public administrations are often considered the realm of bureaucracy and have always had an ambiguous relationship with it, constituting, on one hand, the need for procedural and formal views in order to prevent abuse and injustice and, on the other, the attempt to offer fluid processes and accessible services that positively affect the quality of life for citizens (Ruffini, 2020). That is another paradox; the attempt to debureaucratize has produced more bottlenecks and more bureaucracy.

During emergencies, delayed actions result in severe repercussions. Under the lens of the 21st century objectives detailed by the Agenda 2030, the sanitary system is globally called to immediately address challenges to exit the pandemic crisis. Additionally, states are called to find funds necessary for this exit. However, the problem seems to be endemic and dates back to several decades ago. In fact, as suggested by Wildawsky (1992), a large part of the literature on budgeting in the U.S. is concerned with the use of similar language: economy, efficiency, improvement, or just better budgeting.

The reform of the public sector, which originated between the eighties and nineties in the wake of New Public Management (NPM), started to follow the principles of performance orientation (i.e., performance-related pay) of each public segment, constituting an increasingly private sector-driven ideology in public sector management. A depleted public predisposition to answer its motives is often associated with voluntariness of activity (Lawton, Rayner \& Lasthuizen, 2013, Perry, 2008; 1996;), undermining the sense of social responsibility, compassion, selfsacrifice and commitment to public goals (Vandenabeele, 2011; Diefenbach, 2009; Hood, 1991; Rubin, 2014).

Public budgeting has changed enormously since the seminal articles on budgetary reform as proposed by Levine (1978). The emphasis on cutting spending to balance budgets has intensified the problem of underspending (Rubin, 2014). This concept allows another paradox of recent years to be reinvigorated through the lens of the Covid-19 pandemic: the environmental rebellion to the modifying hand of man.

This view tends to exacerbate existing disparities, empowering the role of financial availability, which more generally evident in budgetary relationships as anti-crisis authoritative leadership. For example, the failures in programming to repair infrastructures, as shown during the last years through bridge collapses, overflowing rivers, floods, the underestimated accommodation capacity of hospitals, the absence of planning and investments in prevention or response to any potential crisis 
situations, etc., would make disasters even debilitating. Therefore, timeliness and appropriately prepared intervention for such eventualities will exposes weakness in almost all HICs, often have to address these exceptional needs with impromptu and unscheduled measures. The difficulties encountered appeared mostly in supra-states, states, and local power relationships deriving from reforms of the last few decades.

The logic of territorial responsibility is expected to yield virtuosity in terms of efficiency; paradoxically, during the emergency, it seems to have demonstrated deficiencies in the timeliness of decision-making between the various levels of government for at least the initial phase. The political aspects underline many territorial discrepancies, which are subsequently balanced by the emergency provisions foreseen at the regulatory level.

Under this lens, the authors examine social, environmental, and economic issues, which can be crucial during emergencies. The authors also assess underlying leadership relations that inevitably affect responsibility in the context of human rights preservation (Welford, 2002).

In the context of extreme difficulty under socio-economic imbalance, the latter is found to be an activator of horizontal cooperative approaches. During the Covid-19 pandemic, the intrinsic timely capability to identify and satisfy needs, inherent in private companies (Zappa, 1957), could be a third way to multidirectionally reach the objective of exiting the crisis. An example of responsible actions made by companies during the pandemic spread are innumerable and include the strong production of social advertising (Rainero \& Modarelli, 2020). CSR efforts including producing media influence (Bandura, 1965) to promote correct social behaviours, running active donations campaigns, and conducting supply chain conversions, have been structured to face challenges in a timely manner, a task that is quite difficult to manage solely through government-sided intervention. In addition, to achieve these goals, consumers' propensity to favours responsible actions contributed to the elevation of CSR from a duty of rational repayment effect to a perfect cooperative reciprocity-based win-win solution. This perspective is dealt with in detail in the following paragraphs.

\section{Theoretical Frame: CSR as a Balanced Reciprocity Relation in Emergencies and as a Strategy to Survive}

Not every social institution can be considered an economic entity per se if extrapolated from an economic mechanism. These ones, as seen in the current model, validly show the connotations of "gears" in a system oriented to the acquisition of scarce goods or services for the satisfaction of needs (Zappa, 1957). The shift from primitive societies to more advanced and modern ones has resulted in the emergence of companies whose actions are devoted to the social function of need satisfaction. In any case these ones are the result of relationships and social interactions that can be defined in terms of mutual utility or in terms of reciprocity, which is not generalized generosity and instead vehiculated by exchange (Sahlins, 2020). On this basis, the proposed study aims to consider CSR as not an ancient concept, but one which currently seems to be linked to atavistic and immanent social perspectives in the human social condition. 
CSR, in this sense, could be reinterpreted as a modern transposition of helping relationships that characterized the transition from rudimentary parental and friendly reciprocity to a more organized form of generalized reciprocal subsistence. The aegis of the control construction and integration mechanisms that have allowed civilisation to emerge and to carry out a culture capable of going beyond primitive visions (Sahlins, 2020) intrinsically produce a bidimensional level of leadership composed of the following: (1) the hierarchical-authoritative one based on budgets and spending availability, and (2) a horizontal reciprocal relation of leadership, based on the rational "gift."

Despite the prerogative of progress, breaking points are visible over prolonged periods of crisis, and external environmental variables necessarily create new social paradigms. On the one hand, there are latent paradigms anchored to instincts and the state of nature, such as supremacy sentiments and individualism; on the other hand, niches of more evolved reciprocity emerge as implicit social pacts of survival over time. In this latter construct, CSR as an anti-crisis mechanism could be absorbed and understood.

As previously mentioned, CSR is considerable not an ancient concept, but a relatively recent perspective. In fact, Öberseder et al. (2011) affirmed ten years ago the definition of CSR as an unclear concept. This confirms the recent emergence of this paradigm. Seminal views (Bhattacharya \& Sen, 2004) linked the CSR concept under the lens of modern society to the economic agents' contributions to societal challenges.

This view probably emerged from and was enhanced by increasing interest in social and environmental problems created by the industrial revolutions; as a result, a sense of generalized urgency moved business entities to balance their impacts. From this perspective, re-emerge questions related to rethinking the economic and social model of globalism, in parallel to renewed moral and ethical issues that are against the spasmodic run to development affecting the environment by means of soil degradation, consumption, generalized pollution and social repercussions (Elbe, 2018; Drucker, 1969; Meyer, 2000).

In reference to responsible actions, companies began to implement a beneficial redistribution of their incomes (e.g., the re-engineering of their production lines in order to reduce pollutants, charitable actions, etc.). In summary, companies started to move a portion of their self-interest to social and environmental goals. This helps in improving generalized well-being (Kotler \& Lee, 2005; Vaal and et al., 2008; Bhattacharya \& Sen, 2004) by operating discretionary activities that contribute to sustainable development (Brown et al., 1987), recognizing an impactful role (OECD, 2001) to be legitimized and balanced by a renewed social role inherent reciprocity.

A company's voluntary contributions to achieve goals for a better society (Mihalache, 2011) shape a kind of social contract (Sacconi, 2007) in a hierarchical perspective of leadership, which is derived from a kind of repayment for past devasting impacts that creates jobs and growth $(\mathrm{OECD}, 2001)$ during non-linear and crisis conditions. The aforementioned social contract could be subverted in a grouporiented performance, typically repayment view of the integration of interests teleologically oriented towards a common cause: an exit from the crisis.

In this sense, especially during non-linear periods on the company's side, there are visible actions related to the production lines' timely reconfiguration to cope with the shortage of health devices, such as the implementation of advertising for social 
purposes to guarantee correct behaviours, free life and health insurance coverage for customers, solidarity, fundraising for charity, etc. On the consumer's side, there is the propensity to acquire and consume firms' and brands' products that are responsibly produced (Chamhuri \& Batt, 2015; Lagerkvist et al., 2015) and depicting wider meanings of economic agents in terms of reciprocity (Gouldner, 1960).

During periods characterised by linearity conditions, the co-existence of economic and social (in)-equalities would structure leadership relations based on powerdivergent human conditions. However, actions of settlement and levelling due to individuals, groups, governments, or, more recently, CSR, flank these perspectives.

The specificity of the vision of the "gift" as a reasoned action (Mauss, 1966) moves away from mere self-interest.

During non-linear periods, such as crises, emergencies, etc., the extremised polarisations of rational-charitable approaches based on authoritative leadership is accompanied by reciprocity. This latter, through the aid of the economic agents as social individuals and the evolution of CSR concepts as anti-crisis solutions, would shape the lines of a balanced reciprocity and emphasise cooperation. In this sense, CSR during emergencies could be elevated to a win-win solution, achieving balanced positive results in reciprocity relations (1) from the side of companies that could continue performing its social-economic role sailing out of the crisis and (2) from the side of consumers that would prefer implementing and promoting, through consumingbehaviours, cooperative, responsible, and virtuous cycles of balanced reciprocity.

In this sense, the passage mentioned above at the introductory level takes on a special character that shifts from a repeated and constant duty in periods of linearity, aimed at the repayment effect, which barters legitimacy, to a wider social role in periods of crisis. In fact, by temporarily and promptly replacing the governmental and political paradigms anchored to budgetary dimensions, companies through CSR actions pursue their propositions voluntarily and in shorter time frames. They are able to amplify their positive impact through the immanent proactive ability to identify needs and satisfy them. Economic agents are primarily social individuals or groups with relationships at the base of their exchange.

Koulouri and Mouraviev (2019) furnish a holistic and multidimensional understanding of cooperation as a form of interaction. As reported by Mann and Stoinescu (2020), literature that is more recent investigates the success factors of cooperative settings, mainly focusing on profit perspectives. The authors, consistent with the dualistic nature of reciprocity and despite the existence of parallel budgetary authoritative leadership approaches, focus their attention on the cooperative relations that emerge.

Three dimensions are intrinsically and interdependently connected to reach common objectives: companies, consumers and the whole society, all cooperating to exit the crisis, which is a societal and environmental challenge. The following scheme graphically shows the interconnection directionality:

(Company $\rightarrow \leftarrow$ Consumer $\rightarrow \leftarrow$ Society) $\rightarrow$ Exit crisis.

\section{Methodological Prospects}

Previous studies observed a growing trend of interest in CSR. Despite the wide range of topics treated, little discussion has been reserved on its influences 
(Fernández-Gago, Cabeza-García \& Godos-Díez, 2020) and its reciprocity role as an anti-crisis solution. According to what was identified as a preliminary gap, the authors decided to investigate this ambit, which is relevant to business research and sustainable development despite it not being largely discussed and implemented.

The strict relations among CSR, social-environmental care, and reciprocity under non-linear conditions reflect unexplored areas. In this direction, the authors focus their attention on the possibility of studying CSR phenomena during an irreproducible event such as the current global pandemic, adequately intersecting the context of environmental collapse observed for years and primary pillars for sustainable development in governments' agendas (e.g., SDGs 2030). These perspectives create a great field of multidimensional investigation. On these lines, the authors began with a systematic investigation aiming to frame the main topics related to CSR that appeared in the journal "Corporate Social Responsibility and Environmental Management" (CSR\&EM) also by Google Scholar Citations (GSC). The procedural operational approach has been graphically reported in Figure 1. In addition, the primary searching activity has been enriched by a broader identification of a gap and inquiries on multiple databases (Figure 2).

Considering the consistency of literary production on the theme and probable underdeveloped areas, the authors implemented a survey-based field analysis conducted on a sample consisting of 288 total respondents (33.7\% males; $66.3 \%$ females), in which two different groups have been structured to effectively verify the presence of CSR activities as horizontal behavioural propensity to reciprocity in coping crisis.

The first group, A, consisted of 80 respondents surveyed prior to the spread of Covid-19 (consistency of the sample: gender: 51, 2\% males and 48, 7\% females; age range: $18-29=18 ; 30-49=43 ; 50-65=16 ; 65$ and beyond $=3$ ).

A questionnaire consisting of fixed questions was submitted to the respondents (Figure 3). The second group, B, consisted of 208 respondents who were surveyed during the first wave of Covid-19 as it spread across Italy (consistency of the sample: gender $-33.7 \%$ males; $66.3 \%$ females; age range: $30-44=47 ; 18-29=3 ; 45-64=158$; 65 and beyond=0).

A questionnaire consisting of eight questions was submitted to the respondents (Figure 4-5). Both questionnaires offer a 5-point Likert scale.

As reported in Figure 1, a specific web-based investigation was planned by the authors. Questioning the specific database of the CSR\&EM journal and concerning the searching criteria "Corporate Social Responsibility" filtered by relevance "anywhere in this journal," research yielded 1,008 results. Following restrictions in the investigation field, the search criteria "pandemic," "anti-crisis," and "COVID19" were added. The results that emerged using "anywhere" as filters are, respectively, 5 results (pandemic), 90 results (anti-crisis), and six results (COVID19). Subsequently filtering by "title" and "keywords," no results seem to be strictly related to the searching criteria.

Following the analysis from the 1,008 results deriving from the "Corporate Social Responsibility" macro-area in the Journal CSR\&EM, the authors, interested in identifying the main topics treated about CSR by "relevance," filtered the main 40 items that appeared by attributing a GSC score in such a way to select the half of the results that emerged in order to proceed with a topic analysis on the 20 most cited papers. This selection process has been useful in determining a lack in the journal 
related to the investigation perspective on CSR as an anti-crisis solution during pandemics, specifically oriented to the recent Covid-19 spread and considering CSR as a multifaceted concept.

Figure 1: CSR\&EM Gap Identification

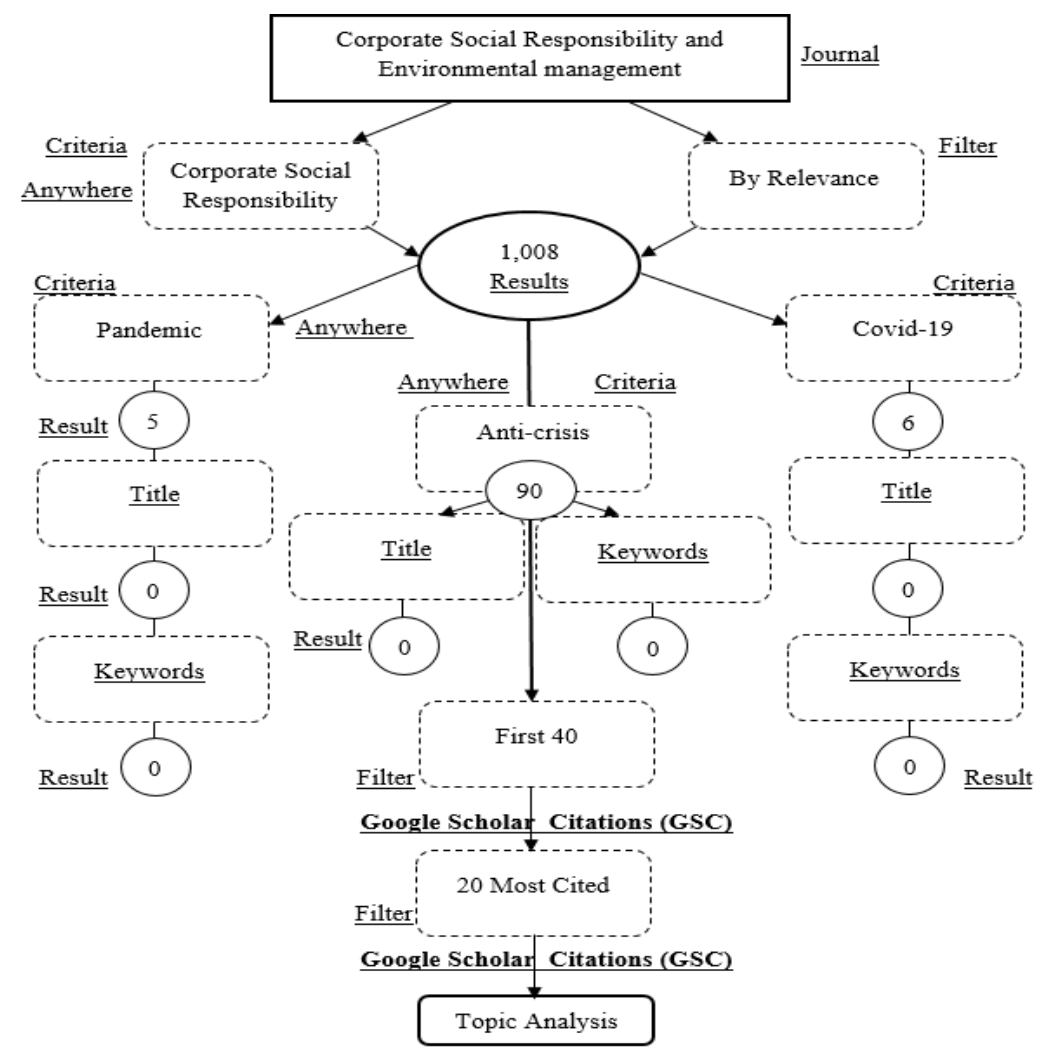

Source: our elaboration.

In addition to the previous approach, another approach was adopted, as reported in Figure 2.

To better enlarge the web-based searching activity on the CSR concept, six databases were queried (Figure 2). The first five databases, Scopus, BusinessSourceUltimate-BSU, EconLit, EbscoHost and ScienceDirect, were queried following two levels of searching criteria: "CSR" or "Corporate Social Responsibility" and "Anti-crisis strategy." The authors filtered the results by article, title, abstract, and keyword and by adding filters within the scope of the journals discussing business and management. While the general searching criteria for the first level generated a huge amount of literary production, the authors, resulting in the return of only two results on Scopus, more specifically restricted the second level. This could be attributed to the fact that results that are more detailed were queried in the database Web of Science. The results that emerged after the 2nd level are as follows: $\mathrm{TI}=5 ; \mathrm{AB}=42 ; \mathrm{KP}=0$. No results were highlighted once the various previous searching criteria were combined.

Therefore, what was highlighted previously is verifiable in through difficult-toaccess and underdeveloped literature on the specific topic of interest. 
Figure 2: Database Investigation

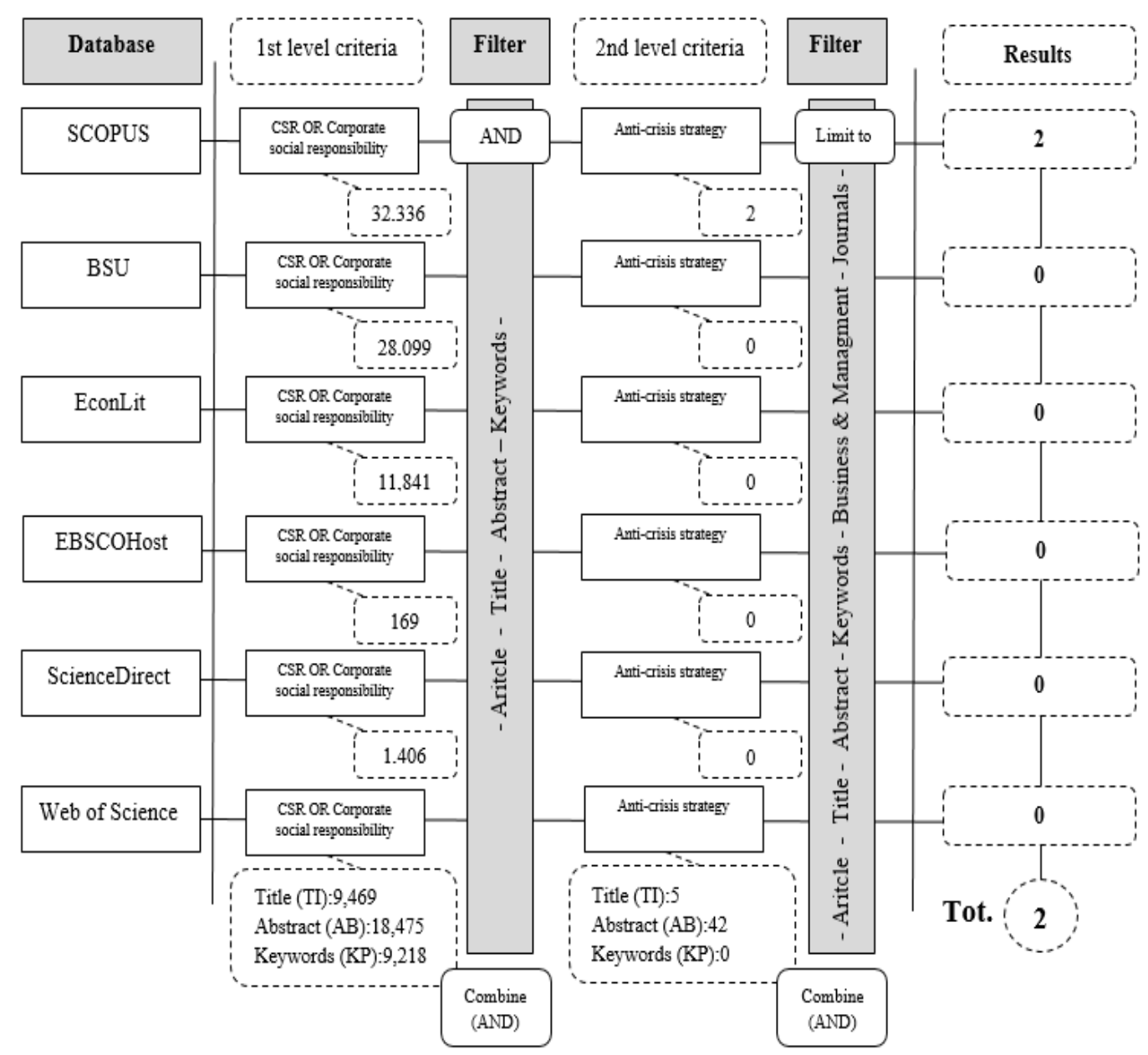

Source: our elaboration.

\section{Results and Data Presentation}

Following the aforementioned assumptions and deriving from the theoretical paradigm used to interpret observable reality, the authors verify consumers' propensity and intention under the influencing constructs of CSR in purchasing and consuming activities prior to and during emergencies. In this sense, reciprocity relations are adequately investigated in parallel with companies' responsible actions toward society in an emergency.

According to the ad hoc structured design, it is possible to shape CSR into a strategic dynamic capability (Ramachandran, 2010). In fact, despite several studies focusing on the existing relationship between CSR and financial performance, a segment of the literature seems to not totally align their results to the crucial and influential role of CSR in consumers' decision-making (Mohr, Webb, \& Harris, 2001); thus the authors properly consider the role played by CSR activities in periods of extreme urgency, emergency, and crisis. The results found seem to be consistent with the ones provided by Ducassy (2012) and Uhlig, Mainardes, and Nossa (2019). 
Figure 3: Sample A Investigation Prior to the Spread of Covid-19

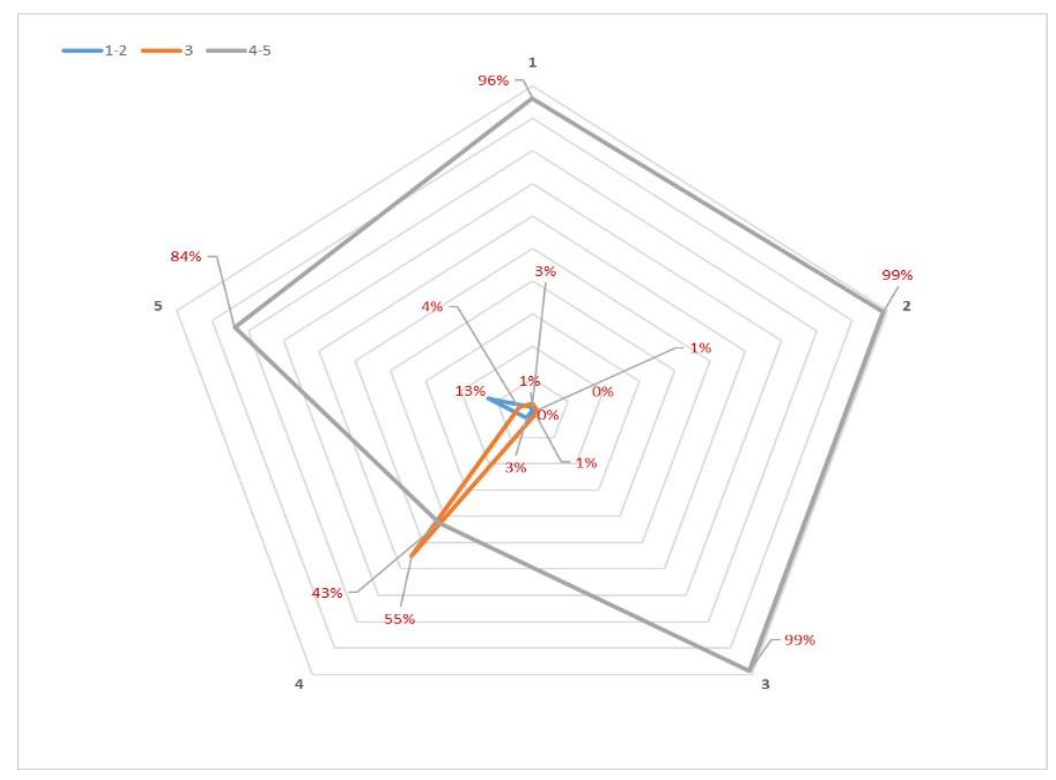

Source: our elaboration.

For the 80 respondents in Group A, it was found that the consumers demonstrated 96\% agreement on the aggregated Likert scale (4-5), affirming that they would tend to purchase and consume products derived from a responsibly-managed production (Figure 3, No. 1). Respondents also affirm that, with almost total agreement (99\%) on the aggregated Likert scale (4-5), they would tend to purchase and consume products that furnish accessibility and data related to responsible production approaches, adding complete information on supply chain traceability (Figure 3, Nos. 2-3). Consumers involved in the survey affirm a strong margin of behavioural change propensity (43\%) on the aggregated Likert scale (4-5); this is potentially related to the possibility and tendency to purchase, in higher quantity, products that guarantee responsible production activities and supply chains in addition to CSR approaches (Figure 3, No. 4). In contrast, 55\% of consumers surveyed demonstrate behavioural change propensity (Likert scale: 3 ). Last but not least, a high percentage (84\%) of respondents is inclined (Likert scale agreement: 4-5), to purchase and consume products that are able to guarantee responsible supply chains and production lines with a reasonable increased price per item measured at 10\%-15\%. By contrast, only $13 \%$ of consumers surveyed demonstrate lower levels of change in spending habits (Figure 3, No. 5).

The data provided frames the consumer-side propensity to provide reciprocity behaviours relative to the achievement of common objectives and challenges during periods of linearity, which may be read as a habitual choice favouring what has been identified as the repayment effect.

The period of Covid-19 spread was aligned to the contingency variable of extreme urgency; what was reported by the analysis of results emerging from sample B comprised of 208 respondents would seem, not to deviate from what expressed in sample A, demonstrating a now generalised awareness and positive relationship between CSR and company performance. 
This can be inferred from consumers' behavioural choices. On the other hand, additional data of considerable informative and interpretative significance on the case of analysis (CSR) during emergencies would suggest this tool could be a useful and timely anti-crisis vehicle in a balanced relationship of reciprocity through cooperativeness.

The consumers involved demonstrate an agreement of $61 \%$, regarding the belief that an effective recent increase in social advertising (from perceived $25 \%$ to $50 \%$ ) has been observed. In addition, a perceived increase greater than $50 \%$ was identified by $29 \%$ of the sample (Figure 4 ).

Figure 4: Sample B Investigation during the Covid-19 Spread-Perceptions on CSR Advertising

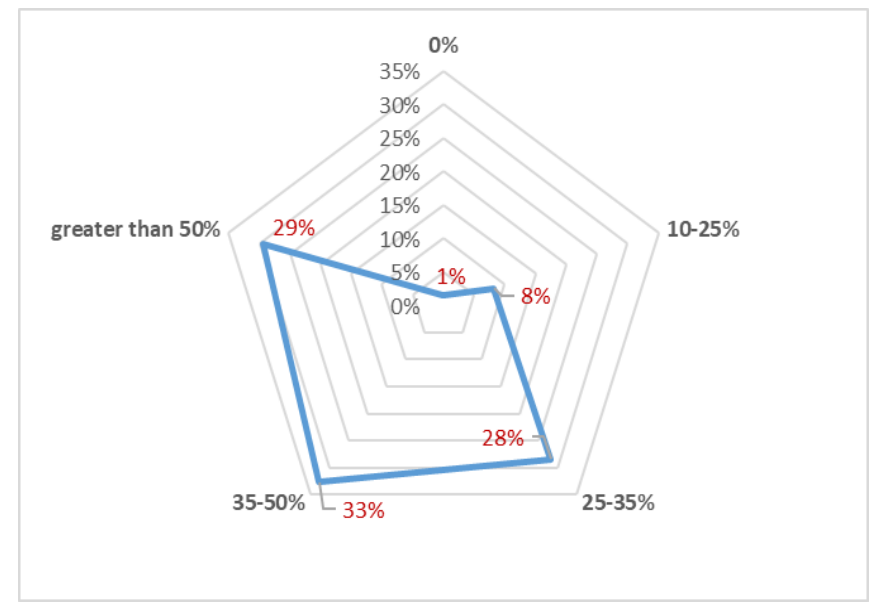

Source: our elaboration.

According to the findings, it is crucial to understand the pervasive role of CSR during emergencies (Ham \& Kim, 2019), in order to demonstrate another paradigm: the social dimension of corporate responsibility in behavioural education during emergencies by the aid of the advertising model, acquiring traits of the aforementioned win-win solution.

Seventy two per cent of respondents affirm (Likert scale agreement: 4-5) that they are convinced that the emergency condition (Covid-19) multiplied CSR actions, volunteering and donation activities (Figure 5, No. 1). These results furnish improved understanding on the companies' behaviours.

Concerning the consumer's awareness during an emergency, it is possible to indicate presence through higher percentage of respondents ( $81 \%$ on the aggregated Likert scale: 4-5) in perfect agreement with a social advertising encouraging the adoption of appropriate behaviours on both the consumers' side and society as a whole (Figure 5, No.2). These results depict the awareness paradigms of consumers on the companies' social responsibilities instead of their economic ones.

The authors measured the tendency to modify behaviours in purchase and consumption choice according to the presence of CSR approaches. In fact, consumers surveyed (in addition to data collected prior to the Covid-19 outbreak) demonstrate a positive increasing propensity (67\% on the aggregated Likert scale: $4-5$ ), toward 
the possibility of purchasing and consuming products whose brands and companies act in a socially and environmentally responsible manner (Figure 5, No.3).

They also affirm an increasing propensity to spend more on products produced by companies that donate to charity (61\% on the aggregated Likert scale: $4-5)$, and that respect the planet (82\% on the aggregated Likert scale: $4-5)$.

In addition, they affirm that social-environmental criteria are crucial factors positively influencing habits in purchasing/consuming decision-making (70\% on the aggregated Likert scale: 4-5) (Figure 5, Nos. 4, 5, and 6).

The results reveal consumers' awareness of the existence of a balanced reciprocity relation between companies, consumers, and society to pursue critical challenges during linear periods by the repayment effect. Due to reciprocity propensity, the timely exit to a crisis requires cooperation from both sides.

In fact, on their side, consumers surveyed would make direct purchase and consumption choices for products promoted through social scope campaigns $(60 \%$ on the aggregated Likert scale: 4-5) (Figure 5, No. 7), aware of the fact that the emergency increased the number of social-environmental responsibility actions through advertising campaigns (68\% on the aggregated Likert scale" 4-5) (Figure 5, No 8). The results provided produce inferences based on the interpretative paradigm used by the authors. In terms of reciprocity, these data open a window on the real voluntariness in balancing risk by CSR as a timely anti-crisis and cooperative winwin solution. The reciprocity relationship existing would effectively shift its motives from the repayment effect, characterizing CSR during moments of linearity, to a generalized will to act through cooperative leadership relationships guided by responsibly oriented strategies for risk mitigation, bidirectionally balanced by rationality in the "gift".

Figure 5: Sample B Investigation during Covid-19

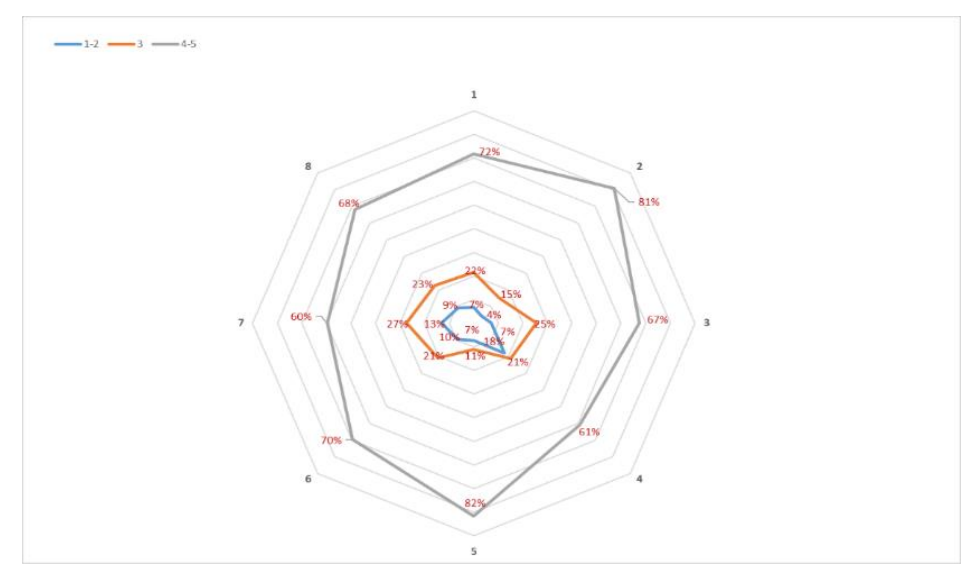

Source: our elaboration.

\section{Critical Discussion}

The spread of Covid-19 is a global emergency period and crisis that demonstrates a tendency to exacerbate inequalities, highlighting on one hand the crucial role of budgeting bargaining power in a game-force on national and international 
negotiation, aligning budgets to authoritative leadership styles (Ajibolade \& Oboh, 2017). On the other hand, the sense of homogeneity would appear as a trait d'union able to enhance the deinstitutionalization of hierarchical practices valid until that moment, moving the ideal towards a balanced reciprocity to reach common goals

Lato sensu governments, individuals, groups, economic agents, etc. have been called to pursue objectives and new challenges. These challenges shape renewed opportunities in terms of leadership (Tizard, 2012; Hartley, 2018), especially under the light of urgency (Boin et al., 2017), as is evident in the global pandemic. These challenges for central states and supranational entities are difficult to reach in a timely manner due to the issues inherent in their structures. In this sense, due to their own characteristics and teleological orientation to recognize and satisfy needs, economic actors could help during crisis. Through a renewed and more conscious view of their role, legitimated by customers, they can be enabled to boost cooperative paradigms and provide timely anti-crisis solutions, at least in the early stages, through CSR strategic approaches.

As early as 2010, Jones (2010) stated that time was not on their side. Despite this, communities have been globally called to follow principles of sustainability and go against an unsustainable economy as framed today. Challenges to save the planet and the ecosystem that is now suffering at the hands of mankind, parallel the achievements of sustainability, maintaining a deadlock for indefinite periods (Kuhlman and Farrington, 2010). In this sense, a renewed and generalized consciousness is needed, starting from agents on the market to consumers and aligning governmental perspectives to responsible actions in commerce and production, from both the customers' and companies' perspectives; precisely, the recent pandemic demonstrates their roles as facilitators in this direction.

Given the added clarity provided by the recent situation, the reforms of past years are now observable. These performance-driven regulations have shown and continue to show glaring weaknesses, especially as regards the budgets for the national health systems, focused on the "economy of the cut" and a mismanagement of performance logic, which often does not equate quality when measured only from internal perspectives. This once again reflects the lethal power of budgets against cooperation.

The proposal to consider a strict relation to relatively delayed public orientations and governmental actions should match the timeliness achievable by the agents on the market. In this sense, the sacrifice of individual budget, although pervasive, would prove observably valid in terms of common objective-driven logic for the long-term goal of survival (Lin \& Wang, 2017).

Recently, the socio-cultural embeddedness of an individual's ethical reasoning in organizations has been studied by several authors, such as Thorne (2002), showing a cognitive-developmental perspective and defining morality as a cognitive conception of what is "good." In this sense, economics cannot exist without ethics; during emergencies, this perspective should be emphasized. The endemic problems characterizing the bureaucratic model dramatically affect the timeliness in crisis response. Discrepancies, inequities in social and economic ambit, and environmental collapse trigger paradigms to open a space in which temporarily economic agents can link their actions with the reciprocity of cooperative sentiments.

In this dynamic, the main aim of CSR, previously identified as a mere repayment effect during linear periods, under external emergency contingencies, is to move 
companies toward a timely and temporary substitution of governmental leadership to achieve its objectives by a procedural power, otherwise known as a "business view." In this sense, companies reach a win-win solution (Kerr et al., 2008). On the one hand, companies safeguard themselves from the effect of the crisis by the consumers' propensity to acquire products responsibly produced or promoted by socialenvironmental redistribution campaigns (Lagerkvist et al., 2015; Chamhuri \& Batt, 2015). On the other hand, companies' need to solving societal challenges is dramatically strengthened by the urgency condition. This relation of balanced "gift" creates a reciprocity scheme, which a form of social contract for cooperative leadership.

\section{Conclusion}

The socio-economic model, under the light of global emergency, seems to stem from a misunderstanding of self-realisation (Maslow, 1943) which is unfortunately mistaken with a spasmodic challenge for supremacy and productivity. In this paradigm, CSR is a controversial fruit of progress and modernity, which shows that: (1) on the one hand, a renewed awareness of moral imperatives; (2) on the other hand, an instrumentally oriented attempt to achieve legitimacy of productive actions to achieve profit (a kind of repayment effect for dangerous impacts).

The emergency variable seems to subvert this dimension, constituting a reciprocity frame of cooperative-based relations.

Among the paradoxes, witness in the study was the fact that the global emergency has brought to the attention of attentive observers certain opportunistic mechanisms that have occurred at an embryonic level with the potential for a plausible relapse. In contrast, situations of social imbalance can activate solutions that return to the concept of "donation," which is contrary to that of "gift." These can be read as overturned Machiavelli's.

Thus, the reciprocity paradigm inherent in CSR during global emergencies replaces the logic of rational maximization, substituting a passionate minimization of risk for both parties and shifting an authoritative leadership (Ajibolade \& Oboh, 2017) to a cooperative one (Torfing, Sørensen \& Bentzen, 2019).

Economic actors, in addition to the operators in the not-for-profit sector, frame a cooperative context enhanced by donations, effective charity actions and social or environmental campaigns, overcoming the limits regarding procedural times at states and supporting situations of necessity and need with direct economic aid.

In today's complex world, CSR reflects an alternative perspective to paradoxes of budgetary authoritative power, shifting on the one hand, the "economy of the cut" and on the other, "the economy of the mere profit" into a "balanced cooperative reciprocity."

The results provided by the survey-based approach seem to be consistent with what was expressed before, despite the fact that it is a largely complex endeavour to understand the real reasons behind the liability actions promoted by companies: ethical, moral, and self-interest. Although these dimensions pertain to an internal sphere that is difficult to investigate, under the lens of emergency and non-linear complexity, the authors limited themselves to observing only external phenomenological expressions. In this direction, socio-economic and environmental 
imbalances have been identified as the main triggers of social solutions. Balanced reciprocity represents a mode of action that reflects a unequivocal cooperativitybased anti-crisis strategy towards a common goal. A balanced exchange of mutual and reasonable accommodation would guarantee the outcome of a temporary but timely win-win solution. It can, on the one hand, ensure the satisfaction of urgent and imminent community needs during the crisis, and, on the other hand, make certain the benefits in terms of survival for the company, which may continue to carry out its social and economic actions during and after the crisis.

Practical implications require the authors to consider the possibility of reflection on the balanced reciprocity behaviour of economic operators during periods of crisis and emergency. The article proposes a multifaceted vision on the subject through a consideration of both the business and consumer perspectives, integrating itself into the broader spectrum of institutional economic action, and interacting with the role of budget and its leadership capability. Major evidence of practical fallout is visible in the shift in the use of large-scale CSR practices in periods of emergency, transforming from a mere repayment effect to cooperation at all levels of balanced reciprocity.

\section{Bibliography}

Afsar, B., Al-Ghazali, B. M., Rehman, Z. U., \& Umrani, W. A. (2020). The Moderating Effects of Employee Corporate Social Responsibility Motive Attributions (Substantive and Symbolic) between Corporate Social Responsibility Perceptions and Voluntary Pro-Environmental Behavior. Corporate Social Responsibility and Environmental Management, 27(2), 769-785.

http://dx.doi.org/10.1002/csr.1843

Ajibolade, S. O., \& Oboh, C. S. (2017). A Critical Examination of Government Budgeting and Public Funds Management in Nigeria. International Journal of Public Leadership, 13(4), 218-242.

http://dx.doi.org/10.1108/IJPL-11-2016-0045

Arrigo E. (2003). Corporate Responsibility in Scarcity Economy. The Olivetti Case. Symphonya Emerging Issues in Management (symphonya.unimib.it), (1), 114-134.

http://dx.doi.org/10.4468/2003.1.10arrigo

Atkins, J. F., Solomon, A., Norton, S., \& Joseph, N. L. (2015). The Emergence of Integrated Private Reporting. Meditari Accountancy Research, 23(1), 28-61.

http://dx.doi.org/10.1108/MEDAR-01-2014-0002

Bandura, A. (1965). Influence of Models Reinforcement Contingencies on the Acquisition of Imitative Response. Journal of Personality and Social Psychology, 1(6), 589-595.

http://dx.doi.org/10.1037/h0022070

Barbeito-Caamaño, A., \& Chalmeta, R. (2020). Using Big Data to Evaluate Corporate Social Responsibility and Sustainable Development Practices. Corporate Social Responsibility and Environmental Management, 27(6), 2831-2848.

http://dx.doi.org/10.1002/csr.2006

Bauman, Z. (2000). Liquid Modernity. Cambridge, UK: Polity Press.

Bhattacharya, C., \& Sen, S. (2004). Doing Better at Doing Good: When, Why, and How, Consumers Respond to Corporate Social Initiatives. California Management Review, 47(1), 9-25.

http://dx.doi.org/10.2307/41166284

Bisio L. (2003). Corporate Responsibility and Corporate Governance in Europe. Symphonya Emerging Issues in Management (symphonya.unimib.it), (1), 99-113.

http://dx.doi.org/10.4468/2003.1.09bisio 
Boin, A., Hart, P., Stern, E., \& Sundelius, B. (2017). The Politics of Crisis Management: Public Leadership under Pressure. Cambridge University Press.

Brondoni S.M. (2003). Network Culture, Performance \& Corporate Responsibility. Symphonya Emerging Issues in Management (symphonya.unimib.it), (1), 8-24.

http://dx.doi.org/10.4468/2003.1.02brondoni

Brown, B. J., Hanson, M. E., Liverman, D. M., \& Merideth, R. W. (1987). Global Sustainability: Toward Definition. Environmental Management, 11(6), 713-719.

http://dx.doi.org/10.1007/BF01867238

Brown, J., \& Dillard, J., (2014). Integrated Reporting: On the Need for Broadening Out and Opening Up. Accounting, Auditing \& Accountability Journal, 27(7), 1120-1156.

http://dx.doi.org/10.1108/AAAJ-04-2013-1313

Brown, J. A., \& Forster, W. R. (2013). CSR and Stakeholder Theory: A Tale of Adam Smith. Journal of Business Ethics, 112, 301-312.

http://dx.doi.org/10.1007/s10551-012-1251-4

Bruni, L., \& Zamagni, S. (2004). Civil Economy, Efficiency, Equity, Public Happiness. Bologna: Il Mulino.

Cardamone, P., Carnevale, C., \& Giunta, F., (2012). The Value Relevance of Social Reporting: Evidence from Listed Italian Companies. Journal of Applied Accounting Research, 13(3), 255-269. http://dx.doi.org/10.1108/09675421211281326

Carroll, A. B. (1979). A Three-Dimensional Conceptual Model of Corporate Social Performance. Academy of Management Review, 4(4), 497-505.

http://dx.doi.org/10.2307/257850

Caselli C. (2003). Ethics and Corporate Responsibility in International Relations. Symphonya Emerging Issues in Management (symphonya.unimib.it), (1), 31-43.

http://dx.doi.org/10.4468/2003.1.04caselli

Chamhuri, N., \& Batt, P. J. (2015). Consumer Perceptions of Food Quality in Malaysia. British Food Journal, 117(3), 1168-1187.

http://dx.doi.org/10.1108/BFJ-08-2013-0235

Chen, R. C., Lee, C. H., \& Hung, S. W. (2020). The Relationship Between Ex-Ante Cost of Equity Capital and Corporate Social Responsibility in Introductory and Maturity Period. Corporate Social Responsibility and Environmental Management, 27(2), 1089-1107.

http://dx.doi.org/10.1002/csr.1867

Cooper, A. F., \& Kirton, J. J. (2009). Innovation in Global Health Governance: Critical Cases. Ashgate Publishing: Burlington.

Darvas, Z. (2010). The Impact of the Crisis on Budget Policy in Central and Eastern Europe. OECD Journal on Budgeting, 11.

De Klerk, M., \& De Villiers, C. (2012). The Value Relevance of Corporate Responsibility Reporting: South African Evidence. Meditari Accountancy Research, 20(1), 21-38.

http://dx.doi.org/10.1108/10222521211234200.

De Villiers, C., Rinaldi, L., \& Unerman, J. (2014). Integrated Reporting: Insights, Gaps and an Agenda for Future Research. Accounting, Auditing \& Accountability Journal, 27(7), 1042-1067.

http://dx.doi.org/10.1108/AAAJ-06-2014-1736.

Di Bernardo, M. (2012). Called to Serve the Common Good: Vocation, Care and Civic Commitment. Milano: FrancoAngeli.

Diefenbach, T. (2009). New Public Management in Public Sector Organizations: The Dark Sides of Managerialistic 'Enlightenment'. Public Administration, 87(4), 892-909.

http://dx.doi.org/10.1111/j.1467-9299.2009.01766.x

Dohmen, T., Enke, B., Falk, A., Huffman, D., \& Sunde, U. (2015). Patience and the Wealth of Nations. Unpublished manuscript. University of Bonn. 
Donahue, A. K., \& Joyce, P. G. (2001). A Framework for Analyzing Emergency Management with an Application to Federal Budgeting. Public Administration Review, 61(6), 728-740.

http://dx.doi.org/10.1111/0033-3352.00143

Drucker, P. F. (1969). The Age of Discontinuity: Guidelines to our Changing Society. Routledge: New York.

Ducassy, I. (2012). Does Corporate Social Responsibility Pay Off in Times of Crisis? An Alternate Perspective on the Relationship between Financial and Corporate Social Performance. Corporate Social Responsibility and Environmental Management, 20(3), 157-167.

http://dx.doi.org/10.1002/csr.1282

Dumay, J., Bernardi, C., Guthrie, J., \& La Torre, M. (2017). Barriers to Implementing the International Integrated Reporting Framework: A Contemporary Academic Perspective. Meditari Accountancy Research, 25(4), 461-480.

http://dx.doi.org/10.1108/MEDAR-05-2017-0150

Eding, E., \& Scholtens, B. (2017). Corporate Social Responsibility and Shareholder Proposals. Corporate Social Responsibility and Environmental Management, 24(6), 648-660.

http://dx.doi.org/10.1002/csr.1434

Elbe, S. (2018). Pandemics, Pills and Politics: Governing Global Health Security. Johns Hopkins University Press: Baltimore.

Evan, W. M., \& Freeman, R. E. (1988). A Stakeholder Theory of the Modern Corporation: Kantian Capitalism. New York, NY: University Press.

Fernández-Gago, R., Cabeza-García, L., \& Godos-Díez, J. L. (2020). How Significant is Corporate Social Responsibility to Business Research? Corporate Social Responsibility and Environmental Management, 27(4), 1809-1817.

http://dx.doi.org/10.1002/csr.1927

Francés-Gómez, P., \& del Rio, A (2008). Stakeholder's Preference and Rational Compliance: A Comment on Sacconi's "CSR as a Model for Extended Corporate Governance II: Compliance, Reputation and Reciprocity”. Journal of Business Ethics, 82, 59-76.

http://dx.doi.org/10.1007/s10551-007-9562-6

Freeman R. E., \& Dmytriyev S. (2017). Corporate Social Responsibility and Stakeholder Theory: Learning From Each Other. Symphonya Emerging Issues in Management (symphonya.unimib.it), (1), 7-15.

http://dx.doi.org/10.4468/2017.1.02freeman.dmytriyev

Freeman, R. E. (1984). Strategic Management: A stakeholder Approach, Pitman, Boston.

Frey, B. S. (2005). Not Just for Money: the Disinterested Motivations of Economic Action. Milan: B. Mondadori.

Friedman, M. (2007). The Social Responsibility of Business Is to Increase Its Profits. In: Zimmerli W.C., Holzinger M., Richter K. (eds). Corporate Ethics and Corporate Governance. Berlin \& Heidelberg: Springer.

http://dx.doi.org/10.1007/978-3-540-70818-6_14

García-Sánchez, I. M., Hussain, N., Khan, S. A., \& Martínez-Ferrero, J. (2020). Managerial Entrenchment, Corporate Social Responsibility, and Earnings Management. Corporate Social Responsibility and Environmental Management, 27(4), 1818-1833.

http://dx.doi.org/10.1002/csr.1928

Getele, G. K., Li, T., \& Arrive, T. J. (2020). Corporate Culture in Small and Medium Enterprises: Application of Corporate Social Responsibility Theory. Corporate Social Responsibility and Environmental Management, 27(2), 897-908.

http://dx.doi.org/10.1002/csr.1853

Godos-Díez, J. L., Cabeza-García, L., Fernández-Gago, R., \& Nieto-Antolín, M. (2020). Does CEO Media Exposure Affect Corporate Social Responsibility? Corporate Social Responsibility and Environmental Management, 27(2), 825-840.

http://dx.doi.org/10.1002/csr.1847 
Gouldner, A. (1960). The Norm of Reciprocity: a Preliminary Statement. American Sociological Review, 25(2), 161-178.

http://dx.doi.org/10.2307/2092623

Hallin, A., \& Gustavsson, T. K. (2009). Managing Death-Corporate Social Responsibility and Tragedy. Corporate Social Responsibility and Environmental Management, 16(4), 206-216. http://dx.doi.org/10.1002/csr.203

Ham, C., \& Kim, J. (2019). The Role of CSR in Crises: Integration of Situational Crisis Communication Theory and the Persuasion Knowledge Model. Journal of Business Ethics, 158, 353-372.

http://dx.doi.org/10.1007/s10551-017-3706-0

Hartley, J. (2018). Ten Propositions About Public Leadership. International Journal of Public Leadership, 14(4, 202-217.

http://dx.doi.org/10.1108/IJPL-09-2018-0048

Hood, C. (1991). A Public Management For All Seasons? Public Administration, 69(1), 3-19. http://dx.doi.org/10.1111/j.1467-9299.1991.tb00779.x

Iglesias, O., Markovic, S., Bagherzadeh, M., \& Singh J. J. (2020). Co-creation: A Key Link Between Corporate Social Responsibility, Customer Trust, and Customer Loyalty. Journal of Business Ethics, 163, 151-166.

http://dx.doi.org/10.1007/s10551-018-4015-y

Jones, E. (2010). A Eurobond proposal to promote stability and liquidity while preventing moral hazard. ISPI Policy Brief, No.180, 1-4.

Ken, W. (2016). Crisis Narratives and the Abandonment of CSR During the Financial Crisis: Notes from Systems Integrated. Social and Environmental Accountability Journal, 36(3), 188-202.

http://dx.doi.org/10.1080/0969160X.2016.1246375

Kerr, G., Johnston, K., \& Beatson, A. (2008). A framework of Corporate Social Responsibility for Advertising Accountability: The Case of Australian Government Advertising Campaign. Journal of Marketing Communications, 14(2), 155-169.

http://dx.doi.org/10.1080/13527260701858539

Kevany, S. (2014). Global Health Diplomacy: a 'Deus ex Machina' for International Development and Relations: Comment on "A Ghost in the Machine? Politics in Global Health Policy". International journal of health policy and management, 3(2), 111-112.

http://dx.doi.org/10.15171/ijhpm.2014.67

Kohn, G. C. (2007). Encyclopedia of Plague and Pestilence: from Ancient Times to the Present, Facts on file. New York.

Kotler, P., \& Lee, N. (2005). Corporate Social Responsibility, Doingthe Most Goodfor Your Company and Your Cause. Hoboken, New Jersey: John Wiley \& Sons Inc.

Koulouri, A., \& Mouraviev, N. (2019). Policy and Governance in the Water-Energy-Food Nexus: a Relational Equity Approach. Routledge: London.

Kuhlman, T., \& Farrington, J. (2010). What is Sustainability? Sustainability, 2(11), 3436-3448.

http://dx.doi.org/10.3390/su2113436

Lagerkvist, C. J, Okello, J. J., \& Karanja, N. (2015). Consumers' Mental Model of Food Safety for Fresh Vegetables in Nairobi. British Food Journal, 117(1), 22-36.

http://dx.doi.org/10.1108/BFJ-09-2013-0280

Lawton, A., Rayner, J., \& Lasthuizen, K. (2013). Ethics and Management in the Public Sector. Routledge

Levine, C. H. (1978). Organizational Decline and Cutback Management. Public Administration Review, 38(4), 316-325.

http://dx.doi.org/10.2307/975813

Lin, Y. J., \& Wang, Y. (2017). The New Structural Economies: Patient Capital as a Comparative Advantage. Journal of Infrastructure, Policy and Development, 1(1), 4-23. 
http://dx.doi.org/10.24294/jipd.v1i1.28

Lovering, J. (1999). Theory Led by Policy: The Inadequacies of the "New Regionalism". International Journal of Urban and Regional Research, 23, 379-395.

http://dx.doi.org/10.1111/1468-2427.00202

Lu, J., Ren, L., Zhang, C., Wang, C., Ahmed, R. R., \& Streimikis, J. (2020). Corporate Social Responsibility and Employee Behavior: Evidence from Mediation and Moderation Analysis. Corporate Social Responsibility and Environmental Management, 27(4), 1719-1728.

http://dx.doi.org/10.1002/csr.1919

Luo, X., \& Zheng, Q. (2013). Reciprocity in Corporate Social Responsibility and Channel Performance: Do Birds of a Feather Flock Together? Journal of Business Ethics, 118(1), 203-213. http://dx.doi.org/10.1007/s10551-012-1582-1

Mann, S., \& Stoinescu, A. (2020). Exploring Draheim's Three Dimensions of Success in Cooperative Organizations - the Case of Collective Alpine Summer Farms. Annals of Public Cooperative Economics, 1-16.

http://dx.doi.org/10.1111/apce.12309.

Martínez-Ferrero, J., Suárez-Fernández, O., \& García-Sánchez, I. M. (2019). Obfuscation Versus Enhancement as Corporate Social Responsibility Disclosure Strategies. Corporate Social Responsibility and Environmental Management, 26(2), 468-480.

http://dx.doi.org/10.1002/csr.1697

Maslow, A. H. (1943). A Theory of Human Motivation. Psychological Review, 50(4), 370-396.

http://dx.doi.org/10.1037/h0054346

Mauss, M. (1966). Essai sur le Don: Forme et Raison de l'Échange dans les Sociétés Archaiques, in Sociologie et anthropologie, Presses Universitaires de France, Paris - Italian translation: Saggio sul dono (2002). Turin: Einaudi.

McLennan, S., \& Banks, G. (2019). Reversing the lens: Why Corporate Social Responsibility is not Community Development. Corporate Social Responsibility and Environmental Management, 26(1), 117-126.

http://dx.doi.org/10.1002/csr.1664

Meyer, J. W. (2000). Globalization: Sources and Effects on National States and Societies. International Sociology, 15(2), 233-248.

http://dx.doi.org/10.1177/0268580900015002006

Mihalache, S. S. (2011). CSR - A Marketing Tool? Annals of Spiru Haret University. Economic Series, Universitatea Spiru Haret, 2(1), 159-164.

Mohr, L. A., Webb, D. J., \& Harris, K. E. (2001). Do Consumers Expect Companies to be Socially Responsible? The Impact of Corporate Social Responsibility on Buying Behavior. Journal of Consumer Affairs, 35(1), 45-72.

http://dx.doi.org/10.1111/j.1745-6606.2001.tb00102.x

Mosca, F., \& Civera, C. (2017). The Evolution of CSR: An Integrated Approach. Symphonya Emerging Issues in Management (symphonya.unimib.it), (1), 16-35.

http://dx.doi.org/10.4468/2017.1.03mosca.civera

Öberseder, M., Schlegelmilch, B. B., \& Gruber, V. (2011). Why Don’t Consumers Care About CSR? A Qualitative Study Exploring the Role of CSR in Consumption Decisions. Journal of Business Ethics, 104, 449-460.

http://dx.doi.org/10.1007/s10551-011-0925-7

OECD (2001). Corporate Social Responsibility: Partners for Progress. OECD Centre for Entrepreneurship, SMEs and Local Development.

Ostrom, E. (1990). Governing the Commons, Cambridge University Press, Cambridge.

Pan, X., Sinha, P., \& Chen, X. (2021). Corporate Social Responsibility and Eco-innovation: The Triple Bottom Line Perspective. Corporate Social Responsibility and Environmental Management, 28(1), 214-228.

http://dx.doi.org/10.1002/csr.2043

Edited by: Niccolò Cusano University

ISSN: 1593-0319 
Park, H. J., \& Ha, M. H. (2020). Corporate Social Responsibility and Earnings Transparency: Evidence from Korea. Corporate Social Responsibility and Environmental Management, 27(3), 1498-1508.

http://dx.doi.org/10.1002/csr.1922

Pepe C. (2003). Global Retailers and Corporate Responsibility. Symphonya Emerging Issues in Management (symphonya.unimib.it), (1), 55-71.

http://dx.doi.org/10.4468/2003.1.06pepe

Perry, J. (1996). Measuring Public Service Motivation; an Assessment of Construct Reliability. Journal of Public Administration Research and Theory, 6(1), 5-22.

http://dx.doi.org/10.1093/oxfordjournals.jpart.a024303.

Perry, J., Brudney, J., Coursey, D., \& Littlepage, L. (2008). What Drives Morally Committed Citizens? A Study of the Antecedents of Public Service Motivation. Public Administration Review, 68(3), 445-458.

http://dx.doi.org/10.1111/j.1540-6210.2008.00881.x.

Qi, L., Wang, L., \& Li, W. A. (2020). Do Mutual Fund Networks Affect Corporate Social Responsibility? Evidence from China. Corporate Social Responsibility and Environmental Management, 27(2), 1040-1050.

http://dx.doi.org/10.1002/csr.1864

Rahman, A. A., Castka, P., \& Love, T. (2019). Corporate Social Responsibility in Higher Education: A Study of the Institutionalisation of CSR in Malaysian Public Universities. Corporate Social Responsibility and Environmental Management, 26(4), 916-928.

http://dx.doi.org/10.1002/csr.1731

Rainero, C., \& Modarelli, G. (2020). CSR for Emergencies: The Two Concepts of Accountability. Corporate Ownership \& Control, 18(1), 78-95.

http://dx.doi.org/10.22495/cocv18i1art7

Report of the World Commission on Environment and Development (WCED) (1987). Our Common Future, Oxford University Press, Oxford.

Rivoli, P. (1995). Ethical Aspects of Investors Behavior. Journal of Business Ethics, 14(4), 265-277. http://dx.doi.org/10.1007/BF00871897

Rubin, I. (2014). Past and Future Budget Classics: a Research Agenda. Public Administration Review, 75(1), 25-35.

http://dx.doi.org/10.1111/puar.12289

Ruffini, R. (2020). Bureaucracy and Work. Risorse Umane, Maggioli, 1, 1-6.

Sacconi, L. (2007). A Social Contract Account for CSR as an Extended Model of Corporate Governance (II): Compliance, Reputation and Reciprocity. Journal of Business Ethics, 75, 77-96.

http://dx.doi.org/10.1007/s10551-006-9239-6

Sahlins, M. (2020). The Economy of the Stone Age. Elèuthera, Milano.

Salvioni, D. M., \& Gennari F. (2019). Stakeholder Perspective of Corporate Governance and CSR Committees. Symphonya Emerging Issues in Management (symphonya.unicusano.it), (1), 28-39.

http://dx.doi.org/10.4468/2019.1.03salvioni.gennari

Sánchez-Torné, I., Morán-Álvarez, J. C., \& Pérez-López, J. A. (2020). The Importance of Corporate Social Responsibility in Achieving High Corporate Reputation, Corporate Social Responsibility and Environmental Management, 27(6), 2692-2700.

http://dx.doi.org/10.1002/csr.1993

Sanclemente-Téllez, C. (2017). Marketing and Corporate Social Responsibility (CSR), Moving Between Broadening the Concept of Marketing and Social Factors as a Marketing Strategy. Spanish Journal of Marketing - ESIC, 21(1), 4-25.

http://dx.doi.org/10.1016/j.sjme.2017.05.001.

Sargiacomo, M. (2015). Earthquakes, Exceptional Government and Extraordinary Accounting. Accounting, Organizations and Society, 42, 67-89. 
http://dx.doi.org/10.1016/j.aos.2015.02.001

Shahzad, F., Rehman, I. U., Nawaz, F., \& Nawab, N. (2018). Does Family Control Explain Why Corporate Social Responsibility Affects Investment Efficiency? Corporate Social Responsibility and Environmental Management, 25(5) 880-888.

http://dx.doi.org/10.1002/csr.1504

Sharma, E. (2019). A Review of Corporate Social Responsibility in Developed and Developing Nations. Corporate Social Responsibility and Environmental Management, 26(4), 712-720.

http://dx.doi.org/10.1002/csr.1739

Simnett, R., \& Huggins, A. L. (2015). Integrated Reporting and Assurance: Where Can Research Add Value? Sustainability Accounting, Management and Policy Journal, 6(1), 29-53.

http://dx.doi.org/10.1108/SAMPJ-09-2014-0053.

Tassinari V. (2003). Social Responsibility in Supply Chain. The Coop Italia Case. Symphonya Emerging Issues in Management (symphonya.unimib.it), (1), 72-83.

http://dx.doi.org/10.4468/2003.1.07tassinari

Tatli, A., Ozbilgin, M., Jonsen, K., Karataş-Ozkan, M., Amaeshi, K., \& Atewologun, A. (2014). Reciprocity as a Way Forward for Diversity Management and CSR Research. Corporate Social Responsibility and Human Resource Management. Edward Elgar Publishing.

http://dx.doi.org/10.4337/9781783476367

Thorne, L. (2002). The Socio-Cultural Embeddedness of Individuals' Ethical Reasoning in Organizations (Cross-cultural Ethics). Journal of Business Ethics, 35, 1-14.

http://dx.doi.org/10.1023/A:1012679026061

Tizard, J. (2012). The Challenges and Opportunities in Contemporary Public Sector Leadership. International Journal of Leadership in Public Services, 8(4), 182-190.

http://dx.doi.org/10.1108/17479881211323571

Torfing, J., Sørensen, E., \& Bentzen, T. O. (2019). Institutional Design for Collective and Holistic Political Leadership. International Journal of Public Leadership, 15(1), 58-76.

http://dx.doi.org/10.1108/IJPL-12-2018-0059

Uddin, S., Siddiqui, J., \& Islam, M. A. (2018). Corporate Social Responsibility Disclosures, Traditionalism and Politics: A Story from a Traditional Setting. Journal of Business Ethics, 151, 409-428.

http://dx.doi.org/10.1007/s10551-016-3214-7

Uhlig, M. R. H., Mainardes, E. W., \& Nossa, V. (2020). Corporate Social Responsibility and Consumer's Relationship Intention. Corporate Social Responsibility and Environmental Management, 27(1), 313-324.

http://dx.doi.org/10.1002/csr.1807

Vaaland, T., Heide, M., \& Gronhaug, K. (2008). Corporate Social Responsibility: Investigating theory and Research in the Marketing Context. European Journal of Marketing, 42(9-10), 927-953.

http://dx.doi.org/10.1108/03090560810891082

Van Zyl, K. (2012). Africa in the Time of Cholera: A History of the Pandemics from 1817 to the Present. South African Historical Journal, 64(2), 373-375.

http://dx.doi.org/10.1080/02582473.2012.673634

Vandenabeele, W. (2011). Who Wants to Deliver Public Service? Do Institutional Antecedents of Public Service Motivation Provide an Answer? Review of Public Personnel Administration, 31(1), 87-107.

http://dx.doi.org/10.1177/0734371X10394403

Walsh, B. (2020). Covid-19: The History of Pandemics. BBC Future.

Warwick, S., \& Dowler, T. (2015). Early Assessments of the Gap Between Integrated Reporting and Current Corporate Reporting. Meditari Accountancy Research, 23(1), 92-117.

http://dx.doi.org/10.1108/MEDAR-02-2014-0026. 
Welford, R. (2002). Globalization, Corporate Social Responsibility and Human Rights. Corporate Social Responsibility and Environmental Management, 9(1), 1-7.

http://dx.doi.org/10.1002/csr.4

Wildawsky, A. (1992). Political Implications of Budget Reform: A Retrospective. Public Administration Review, 52(6), 594-599.

http://dx.doi.org/10.2307/977170

Yang, Y., \& Stohl, C. (2020). The (In) Congruence of Measures of Corporate Social Responsibility Performance and Stakeholder Measures of Corporate Social Responsibility Reputation. Corporate Social Responsibility and Environmental Management, 27(2), 969-981.

http://dx.doi.org/10.1002/csr.1859

Zappa, G. (1957). Le Produzioni nell'Economia delle Imprese (in Italian). Turin: Giuffrè.

Zimmerman, B., Lindberg, C., \& Plsek, P. (1998). Edgeware: Insights from Complexity, Health Care Leaders. Irving, TX: VHA. 